\title{
Studi fenomenologi tentang motif dan aturan pertemanan virtual di kalangan pengguna Twitter
}

\author{
Intan Dwi Lestari ${ }^{1}$, Yun Fitrahyati Laturrakhmi ${ }^{2}$ \\ ${ }^{1,2}$ Universitas Brawijaya, Malang, Indonesia
}

\begin{abstract}
ABSTRAK
Berbagai diskusi keilmuan telah mengkonfirmasi bahwa kehadiran new media berdampak secara signifikan terhadap bagaimana komunikasi digunakan untuk membangun dan memelihara hubungan. Demikian pula pada konteks hubungan pertemanan yang tidak lagi bergantung pada komunikasi offline face-to-face dan melibatkan identitas riil individu di dalamnya untuk dapat terbangun dan terjaga keberlangsungannya. Hasil literature review menunjukkan bahwa studi-studi tentang hubungan pertemanan lebih banyak berfokus pada bagaimana hubungan dibangun dan dipelihara, sedangkan studi yang mengarah pada bagaimana aturan dibangun di dalam hubungan pertemanan masih relatif terbatas. Di sisi lain, aturan (rules) merupakan salah satu komponen penting dalam menentukan bagaimana hubungan berjalan atau bahkan terputus. Mencermati kondisi tersebut, penelitian ini dilakukan dengan tujuan mengeksplorasi dan mendeskripsikan bagaimana bentuk aturan pada hubungan pertemanan (close-friendship) yang dibangun melalui akun virtual anonim di media sosial twitter serta kaitannya dengan motif yang mendasari dibangunnya hubungan tersebut. Di bawah kerangka konsep fenomenologi sosial, penelitian ini melibatkan empat wanita yang merupakan pengguna twitter dengan akun anonim. Teknik pengumpulan data dilakukan melalui wawancara mendalam. Hasil penelitian ini menunjukkan bahwa melalui twitter dengan akun anonim, masing-masing informan telah membangun hubungan friendship of reciprocity dengan mutual-nya sebab di dalam hubungan tersebut telah muncul mutual positive regards melalui adanya kepercayaan, dukungan emosional, dan keberbagian minat. Ditemukan pula bahwa perbedaan motif yang mendasari dibangunnya hubungan pertemanan dengan akun anonim tersebut memunculkan bentuk aturan yang berbeda. Berdasarkan penelitian ini, rekomendasi yang diberikan untuk penelitian selanjutnya yaitu perlunya melakukan eksplorasi terhadap aturan dalam jenis hubungan cross-sex friendship relationship maupun romantic relationship yang dibangun melalui akun anonim pada media sosial.
\end{abstract}

Kata-kata kunci: Twitter; anonim; hubungan pertemanan; aturan; motif pertemanan

\section{A phenomenological study on motives and virtual friendship rules among Twitter users}

\section{ABSTRACT}

Studies have confirmed that the advance of new media brings notable impacts on the way people use communication in developing and maintaining relationships. This also emerges in friendship relationships which no longer rely on both offline face-to-face communication and real identities to develop and maintain a meaningful relationship. Previous research on friendship relationships focused more on relationship development stages, involving escalation and de-escalation processes. Nevertheless, research in friendship rules and its role in relational maintenance still outnumbered. Academically, rules become an essential component in most close relationships as they determine how relationships are maintained or might be broken. This research explores and describe rules in close friendship which developed through anonymous virtual accounts on twitter and its relation to the motives underlying the development of these relationships. Using social phenomenology framework, this study involved four women who are users of Twitter with anonymous accounts. The data collection technique was carried out through in-depth interviews. The results of this study indicate that through anonymous account on Twitter, each informant has built a relationship of friendship of reciprocity with their mutual, because mutual positive regards exist in their friendship and it shows through the presence of trust, emotional support, and shared interests. This study also found that the different motives underlying the establishment of the friendship with the anonymous account gave rise to different forms of rules. Further research could explore the rules in the types of cross-sex friendship relationships and romantic relationships that are built through anonymous accounts on social media.

Keywords: Twitter; anonym; friendship relationship; rules; friendship motives

Korespondensi: Intan Dwi Lestari, S.I.Kom. Universitas Brawijaya. Jl. Veteran, Ketawanggede, Kec. Lowokwaru, Kota Malang, Jawa Timur 65145.Email: intan.dwil@student.ub.ac.id 


\section{PENDAHULUAN}

Salahsatujenishubunganinterpersonalyang dapat terbangun melalui media termediasi adalah hubungan pertemanan. Hubungan pertemanan tersebut tidak lepas dari peran komunikasi interpersonal melalui media termediasi. Hal ini seperti yang dikutip dari Wood bahwa komunikasi interpersonal merupakan cara utama untuk membangun, memperbaiki, bahkan mengubah suatu hubungan. Wood menyatakan bahwa komunikasi interpersonal menumbuhkan pengetahuan personal atau personal knowledge yang baik untuk memperdalam hubungan antara dua orang. Personal knowledge merupakan suatu proses yang tumbuh dan berkembang dari waktu ke waktu ketika individu berkomunikasi secara pribadi yang dapat membantu individu untuk mengenal orang lain secara pribadi dan memahami pikiran serta perasaan mereka (Wood, 2010).

Komunikasi interpersonal yang termediasi dikaji dalam $C M C$ atau computer mediated communication. Walther dalam kajiannya yaitu Social information processing perspective, menjelaskan bahwa CMC memang tidak dapat menyampaikan "rasa" dari pesan, namun pengguna dapat beradaptasi pada aliran pesan bahasa dan perilaku tekstual (Walther, Anderson, \& Park, 1994). Menurut Berger, et al (2014:705) bahwa bentuk komunikasi yang terjadi dalam medium teknologi dianggap tidak efektif karena ketiadaan isyarat sosial dalam komunikasi tersebut, namun CMC di satu sisi tidak terikat dalam norma, lebih agresif, juga lebih tanpa hambatan jika dilihat secara umum. Kemudahan yang diperoleh dari CMC membuat beberapa individu lebih nyaman ketika berkomunikasi dengan medium teknologi. Komunikasi yang termediasi internet ini dapat juga disebut sebagai komunikasi virtual. Salah satu konsep dasar dari komunikasi virtual adalah cyberspace atau dunia maya yaitu proses komunikasi menggunakan perangkat komputer serta jaringan internet (Severin \& Tankard, 2011). Komunikasi virtual yang termediasi internet ini membentuk kerjasama dan interaksi antar individu hingga pelibatan terhadap emosi secara virtual (Nasrullah, 2014). Hal ini dapat membentuk komunitas virtual sebagai fenomena sosial yang baru.

Data yang diambil dari penelitian Parks dan Floyd yang melihat sampai sejauh mana hubungan pribadi dapat terbentuk secara online, menunjukkan bahwa dua pertiga responden mengaku sudah memulai hubungan pribadi dan memiliki hubungan pertemanan yang baik dengan orang lain yang mereka temui secara online (Wood \& Smith, 2005; Wood, 2010).

Penelitian ini berfokus pada salah satu media yang termediasi yaitu Twitter. Twitter adalah jejaring sosial micro-blog yang memungkinkan 
penggunanya untuk berkicau atau men-tweet dalam 280 karakter (Ratnasari, 2017). Twitter juga memungkinkan penggunanya untuk terhubung dengan siapa saja, mempublikasikan profil mereka, serta menjalin komunikasi dengan pengguna yang lainnya (Rouis, 2011).

Sebagai media sosial, Twitter mendukung anonimitas. Hutchinson (2017) menyatakan bahwa pengguna Twitter dapat memilih nama mereka menjadi apa pun yang mereka inginkan. Anonimitas merupakan istilah yang menunjukan kondisi dimana identitas sumber pesan diketahui sebagian atau tidak sama sekali dan sengaja disembunyikan dari penerima pesan (Arrini, 2019). Individu menjadi pengguna anonim karena merasa lebih nyaman dan lebih bebas mengungkapkan diri mereka saat berinteraksi secara online (Ardi, 2017; Waskul \& Douglas, 1997).

Anonimitas sering digunakan oleh banyak orang, beberapa diantaranya adalah informan yang menjadi narasumber peneliti. Para informan menggunakan akun anonim di media sosial Twitter. Mereka menggunakan akun anonim karena merasa komunikasi interpersonal yang mereka jalani di Twitter lebih terbangun dan berjalan baik. Dari komunikasi dapat bertumbuh menjadi sebuah hubungan interpersonal. Karena melalui akun anonim mereka bebas mengekspresikan dirinya. Seperti yang dikemukakan oleh Berger, et al
(2014:705) dengan medium teknologi, individu akan lebih leluasa dalam mengungkapkan diri mereka karena anormatif dan lebih minim hambatan. Sehingga perkembangan teknologi dalam bidang komunikasi telah menciptakan suatu cara baru dalam berkomunikasi, yaitu anonimitas, di mana fitur anonimitas yang tersedia ini dimanfaatkan oleh individu untuk berinteraksi dengan orang lain dan menemukan teman.

Salah satu komponen penting yang turut mewarnai dinamika hubungan interpersonal adalah aturan yang ditetapkan dalam hubungan, yang secara akademis seringkali disebut sebagai relationship rules. Rules atau aturan diperlukan untuk mengkoordinasikan perilaku peserta dalam interaksi, pemeliharaan kualitas hubungan, mempertahankan imbalan atau rewards, dan meminimalkan konflik (Argyle \& Anderson, (1984).

Dalam konteks aturan dalam hubungan pertemanan, Wood (2010) mengemukakan bahwa friendship rules merupakan pemahaman tidak tertulis yang mengatur bagaimana orangorang berinteraksi. Dikemukakan pula bahwa aturan pertemanan menyangkut apa yang diinginkan dan diharapkan dari individuindividu yang berteman satu sama lainnya, contohnya adalah dukungan, waktu, dan penerimaan (Wood, 2010). Penggunaan aturan informal dalam pertemanan juga merupakan 
cara untuk mencapai kepuasaan yang lebih besar di dalam hubungan pertemanan (Argyle \& Anderson, 1984). Begitu juga dengan pertemanan virtual yang menggunakan akun anonim di Twitter, hubungan pertemanan juga dilandasi dengan kesepakatan-kesepakatan yang kemudian disebut sebagai aturan/rules.

Kajian atau penelitian yang berfokus pada aturan pertemanan virtual menggunakan akun anonim di media sosial Twitter. Sebagaimana dikemukakan oleh Bryant \& Marmo bahwa, "the existence of interaction rules is commonly accepted byrelationshipresearchers, yetreceives relatively little focused attention" (Bryant \& Marmo, 2012). Tren yang sama berlaku pula dalam konteks friendship relationship. Hal ini diperkuat oleh studi yang menegaskan bahwa perhatian para peneliti sekarang ini lebih terfokus pada hubungan keluarga, romantis, dan pernikahan, walaupun sebenarnya hubungan pertemanan lebih kompleks karena terbentuk dari sejumlah besar individu yang berasal dari latar belakang kehidupan yang mungkin berbeda (Bubas \& Bratko, 2008).

Tema-tema tentang relationship rules khususnya dalam friendship relationship cenderung berangkat dari paradigma positivistik dengan melibatkan serangkaian skala atau ceklis tentang rules yang dibuat oleh peneliti dan disetujui atau tidak disetujui oleh informan. Padahal, aturan dalam sebuah hubungan bersifat unik sebab ia merupakan shared beliefs atau keyakinan bersama tentang hal yang boleh dan tidak boleh (Argyle \& Anderson, 1984), dan ditetapkan oleh orang-perorang yang berada di dalam hubungan (DeVito, 2011). Ketika hubungan terbentuk dengan cara yang berbeda, maka aturan yang ditetapkan pun akan berbeda bergantung pada karakteristik hubungan dan individu yang tinggal di dalam hubungan. Penelitian ini spesifik menyoroti aturan di dalam pertemanan yang sudah masuk dalam tahap teman dekat atau close friendship karena lebih banyak aturan yang mengatur di dalam hubungannya (Bryant \& Marmo, 2012).

\section{METODE PENELITIAN}

Metode penelitian yang digunakan adalah fenomenologi. Menurut Griffin (2009), fenomenologi sebagai salah satu term filsafat pada dasarnya merupakan intentional analysis terhadap pengalaman sehari-hari dari sudut pandang individu yang mengalaminya. Creswell menjelaskan bahwa pendekatan fenomenologi berupaya untuk menjelaskan makna pengalaman hidup sejumlah orang mengenai suatu gejala atau konsep, termasuk pandangan hidup mereka atau konsep diri (Kuswarno, 2007). Penelitian ini menggunakan metode fenomenologi khususnya dengan mengikuti pemikiran Alfred Schutz melalui fenomenologi sosial.

Di dalam fenomenologi sosial yang 
dipengaruhi oleh pemikiran Husserl tentang tipifikasi dan Weber tentang tindakan sosial, Schutz tertarik pada bagaimana anggota masyarakat menciptakan dunia keseharian, khususnya bagaimana individu secara sadar membangun makna dalam interaksinya dengan orang lain (Nindito, 2005; Creswell, 1998). Dalam bahasa yang sedikit berbeda, Fereday \& Muir-Cochrane mengemukakan bahwa Schutz menekankan pada aspek spasial dan temporal atas pengalaman dan relasi sosial (Fereday \& Muir-Cochrane, 2006). Lebih lanjut, salah satu kritik Schutz terhadap Weber tentang tindakan sosial bermuara pada munculnya konsepsi tentang 2 motif yang mendasari tindakan manusia, yaitu in order-to motive dan because motive (Schutz, 1972; Kuswarno, 2009). Dalam penelitian ini, pemikiran Schutz menjadi penting untuk memahami bagaimana pengguna Twitter dengan akun anonim memaknai hubungan pertemanan yang mereka bangun, motif yang mendasarinya, serta peranannya pada bentuk aturan yang dibangun di dalam hubungan tersebut.

Secara teknis, penelitian ini melibatkan empat informan yang merupakan pengguna Twitter lebih dari satu tahun dan menjalin close-friendship secara virtual dengan mutual mereka dengan menggunakan akun anonim. Data diperoleh melalui serangkaian proses wawancara mendalam sehingga diperoleh informasi yang bebas sekaligus mendalam sebab tidak ada kontrol atau pengaruh langsung dari peneliti atas informasi yang diberikan informan, sebagaimana dikemukakan Kriyantono. Proses analisis data dilakukan melalui teknik analisis data fenomenologi mengikuti tahapan yang dirumuskan Creswell. Adapun tahapan yang digunakan meliputi deskripsi fenomena, horizonalisasi, cluster of meaning, dan deskripsi esensi (Hasbiansyah, 2005; Kuswarno, 2009; Creswell, 2013).

\section{HASIL DAN PEMBAHASAN}

Twitter merupakan media sosial berbasis micro-blogging yang memungkinkan penggunanya untuk mengirim dan menerima pesan yang dinamakan tweet (kicauan) (Sari, 2014). Dengan demikian, tulisan atau katakata menjadi fitur utama dari media sosial Twitter. Berdasarkan penelitian yang sudah dilakukan, informan menyatakan bahwa tujuan menggunakan akun anonim dalam media sosial Twitter adalah untuk mengekspresikan rasa terhadap minatnya. Hal tersebut menjadi dasar terbentuknya hubungan pertemanan karena secara sengaja maupun tidak disengaja, individu akan mengikuti atau memfollow akun yang sering membicarakan minat individu tersebut, yang tentunya akun tersebut dikelola oleh perorangan. Sebagaimana disampaikan salah satu informan: 
"Untuk apanya ya karena itu karena kalo nyari temen asli yang interest nya sama kayak yang suka korea-korea gitu kan kadang ada yang ga suka korea ya, jadi kayak agak males gitu lah ngomonginnya tapi kalo di Twitter kayak lebih leluasa aja ngomonginnya". (CT, 26 Desember 2019).

Informan lain pun juga mendukung pendapat ini. "Jadi kita lebih banyak bisa ngomongin suatu hal yang sama entertainment aja yaa have fun gitu aja sih" (BLD, 1 Januari 2020).

Hal ini sesuai pendapat dari Tang bahwa pemicu terbentuknya pertemanan online atau virtual adalah adanya kesamaan pemikiran, kepentingan, serta minat (Tang, 2010). Interaksi yang intens antar individu lewat akun masingmasing membentuk hubungan pertemanan di media sosial Twitter. Seperti yang dijelaskan oleh salah satu narasumber, yaitu NM:

"Yang jelas yang paling sering berhubungan yaa karena mutual itu banyak (dalam konteks siapa yang bisa menjadi teman dekat), tapi gak banyak yang sering mention-mentionan, dm-dm an itu gak banyak. Itu satu. Terus yang kedua mungkin nih yaa dari, obrolannya. Bisa dari K-pop, bisa dari non-K-pop. Biasanya kalo pertemanan yang udah deket itu biasanya sering juga ngomongin seputaran di luar K-pop gitu”.

Selanjutnya, Twitter sebagai media sosial berbasis microblogging juga memungkinkan penggunanya untuk anonym, yaitu pengguna tidak menunjukan foto diri, identitas asli, serta informasi tentang dirinya yang sebenarnya.
Berkaitan dengan hal tersebut, temuan dalam penelitian ini menunjukkan bahwa meskipun menggunakan akun anonim informan telah menjalin hubungan pertemanan bahkan hingga pada tahap close friendship atau teman dekat.

Waskul \& Douglas menjelaskan bahwa individu menjadi pengguna anonim karena merasa lebih nyaman dan lebih bebas mengungkapkan diri mereka saat berinteraksi secara online (Waskul \& Douglas, 1997). Dari hasil penelitian ini diketahui bahwa informan lebih nyaman beranonim karena dapat mengekspresikan diri mereka tanpa mengkhawatirkan identitas mereka. Dengan beranonim mereka dapat mengekspresikan minatnya tanpa takut orang lain akan terganggu atau tanpa takut orang lain akan melabeli dirinya dengan hal yang buruk. Dalam penelitian ini kenyaman dalam beranonim ditunjukan oleh salah satu informan yang beranggapan bahwa di akun anonim dirinya bisa 'sambat' (berkeluh kesah) maupun berkata kasar dan bisa leluasa menunjukan sisi negatif dari dirinya. Seperti yang disampaikan oleh salah satu informan, "Gua tuh sambat, ehm. Cerita tentang temen-temen real gue yang ga mungkin gue ceritain ke lingkungan temen-temen gue, terus banyak orang yang gak tau gua masih ngomong kasar apa segala macem, nah gua tuh kayak lebih leluasa aja ngomong disana (Twitter) kayak gitu loh negative side nya gua lah disitu (Twitter) sebenernya”. (CT, 26 Desember 2019).

Para informan mengemukakan bahwa 
hubungan yang mereka jalin tidak secara otomatis mengarah pada hubungan pertemanan. Dibutuhkan proses komunikasi interpersonal dan pengungkapan diri dengan kedalaman dan keluasan tertentu. Peneliti menemukan bahwa intensitas komunikasi menjadi sangat penting dalam hubungan pertemanan online karena dalam sebuah pesan yang diberikan ada informasi mengenai individu yang nantinya menjadi personal knowledge bagi individu yang lain. Menurut Woods personal knowledge adalah suatu proses yang tumbuh dan berkembang dari waktu ke waktu ketika individu berkomunikasi secara pribadi yang dapat membantu individu untuk mengenal orang lain secara pribadi dan memahami pikiran serta perasaan mereka (Woods, 2010). Pernyataan Woods sesuai dengan pendapat salah satu informan yang mengemukakan,

"kalo udah bener-bener temen deket online itu tandanya tuh udah sering denger aku cerita tentang kehidupan real. Meskipun dia belum tau siapa aku aslinya, misalnya kayak "eh gue abis ginigini deh sama temen gue" "toxic ga sih" kayak gitu-gitu kan kayak cerita-cerita gitu atau nanyain saran kayak kemaren juga sempet sih kayak kado buat temen offline aja tuh nanya sarannya sama temen online. Nah, kalo udah deket banget itu bisa sampe tukeran socmed real itu udah tahapnya aku udah nunjukin siapa aku sebenernya kayak nama aku siapa, kuliah dimana ..."(CT, 26 Desember 2019).

Artinya informasi antar personal diperoleh setelah melalui proses yang panjang dan berkembang setelah keduanya merasa dapat terkoneksi dan saling percaya satu sama lain. Jika dikaitkan dengan jenis-jenis pertemanan berdasarkan klasifikasi DeVito, maka pertemanan yang dijalin oleh para informan termasuk dalam tipe friendship of reciprocity.

Seperti yang dijelaskan Reisman bahwa hubungan reciprocity yaitu hubungan antara dua individu yang berbagi dengan adil dalam memberi maupun menerima manfaat dan penghargaan, dicirikan dengan adanya pengorbanan diri, saling menguntungkan, kesetiaan, dan kemurahaan hati (DeVito, 2013). Pada tahap awal kedua individu saling mengikuti, untuk membangun hubungan pertemanan dibutuhkan peran dari komunikasi interpersonal. Menurut para informan munculnya hubungan pertemanan, selain karena minat yang sama yang sudah dijelaskan di atas juga muncul dari seringnya mereka berkomunikasi antara satu sama lain.

Komunikasi yang dilakukan oleh pengguna dilakukan melalui fitur-fitur yang tersedia di Twitter seperti mention, reply, $R T$, quote, $D M$, dan likes. Hal ini diungkapkan oleh informan BLD, “Kayak gua mulai ngepost gambar trus gue mention mereka trus mereka menanggapi, gitu sih awalnya". Informan NM juga menambahkan:

"Waktu itu dia sempet nyari temen juga katanya dia pengen curhat, soal temennya yang depress dan segala macem, akhirnya aku awalnya dari mention dulu trus kita akhirnya dm-dm an. Terus semenjak itu jadi 
deket kayak sering ngobrol, ngomongin banyak hal".

Dari hasil penelitian diketahui bahwa masing-masing dari informan sudah menunjukan hubungan pertemanan berjenis reciprocity. Menurut Vaquera \& Kao, friendships that are reciprocated are likely to be more emotionally supportive as well as a superior resource compared to friendships that are not reciprocal (Vaquera \& Kao, 2008). Dalam penelitian ini hal tersebut ditunjukan dengan adanya dukungan emosional antara informan dengan mutual-nya berupa kebiasaan saling sapa pada saat salah satu di antara mereka membuat tweet, mendengarkan atau menyimak, memberikan feedback, memberikan rasa ketenangan, berusaha menempatkan diri di posisi informan/ mutual, dan berpihak kepada mutual/informan.

Dukungan emosional yang diberikan diakui dapat membuat informan tenang serta merasa dirinya terdukung karena ada orang yang berada di sisinya. Seperti yang dijelaskan oleh salah satu informan yang mendapatkan dukungan emosionalnya di pertemana online:

"Gua kalo ada masalah cerita di Twitter terus mereka kayak nanya kenapa, ada apa gitu. Kenapa dan ada apa aja tuh berarti banget sih, kayak oh berarti ni ada yang peduli ama gue.. Itu ditanya kayak gitu aja udah hubungan emosional ya menurut gue ya. Dari situ mereka nyemangatin, ngasih saran. Sebenernya gua ga butuh saransaran banget yaa karena kan kejadian ini kejadiann nyata gue ya, orang gak tau sebenernya apa yang gua hadapin secara langsung cuman, ya gua menerima lah saran mereka yaudah mereka jadi pendengar yang baik aja tuh udah baik banget sih, udah dukungan emosional banget sih buat gue karena ngaruh sih bisa nenangin juga".

Dukungan emosional tersebut juga merupakan salah satu dari karakteristik mutual positive regards. Mutual positive regards adalah batasan bahwa sebuah hubungan merupakan hubungan pertemanan. Secara konseptual, sebuah hubungan sendiri dapat didefinisikan sebagai hubungan pertemanan jika hubungan interpersonal di antara dua individu tersebut saling produktif dan mempunyai karakteristik yaitu penghormatan yang positif atau mutual positive regard (DeVito, 2013). Temuan dalam penelitian ini menunjukkan bahwa para informan sudah membangun hubungan pertemanan online dengan mutual-nya yang ditandai dengan pengakuan bahwa mutualnya adalah teman dekatnya, lalu hubungan yang terjalin merupakan hubungan yang saling produktif dan tidak merusak, serta adanya penghormatan yang positif atau mutual positive regards. Dengan demikian, dapat disimpulkan bahwa hubungan yang dijalin para informan dengan mutual-nya merupakan hubungan interpersonal dalam jenis pertemanan.

Lebih jauh DeVito mengemukakan bahwa karakteristik dari mutual positive regards adalah adanya dukungan emosional, yang telah 
dijelaskan di atas, berbagi minat, dan adanya kepercayaan (DeVito, 2013). Dalam kaitannya dengan penelitian ini, hasil wawancara menunjukkan bahwa dalam membangun hubungan interpersonal pertemanan di Twitter, informan menggunakan cara yang beragam, sebagian besar dari mereka mengikuti akunakun yang sering membicarakan minat yang sama dengan informan dalam kata lain adalah melalui algoritma Twitter, sedangkan sebagian lainnya memanfaatkan auto-base. Dikutip dari mojok.co, auto-base adalah media berupa akun yang memfasilitasi pengguna Twitter untuk mengirimkan tweet secara anonim, yang cara kerjanya adalah dengan mengirimkan DM ke akun tersebut dengan kode tertentu, dan pesan akan otomatis ter-post tanpa mengetahui siapa pengirim pesan (Fahmi, 2019).

Auto-base memudahkan informan untuk mencari teman atau mutual yang mempunyai minat yang sama dengan mereka, karena tidak jarang isi pesan anonim yang dikirim melalui auto-base berisi ajakan untuk menjadi teman/ mutual yang mau mengikuti satu sama lain. Hal ini seperti yang diungkapkan oleh narasumber:

"Pertama, saya tuh menggunakan base juga sih jadi ada autobase yang autopost, jadi disitu kayak ayo mutualan sama aku siapa yang mau, nah nanti banyak tuh yang ngereply nah dari situ langsung lah ngefollow-follow-in". Narasumber lain juga menambahkan, "Awal-awal ketemunya yaa.. awal-awal ketemunya tuh kalo ga salah kayak ada base, nyari temen yang satu line gitu loh. Terus abis itu, kenal-kenal-kenalan eh ketemu satu yang cocok nih sampe bisa lanjut dm-dm-an. Ternyata orangnya seru lah, maksudnya masuk lah sama ini gua, apa sih sama tipetipe pertemanan gua gitu”.

Mencari teman dengan minat yang sama melalui auto-base dapat dilihat dari kacamata sharing of interest yang merupakan salah satu kriteria pertemanan berdasarkan mutual positive regards. Karakteristik mutual positive regards yang terakhir sebagaimana dikemukakan DeVito adalah trust atau kepercayaan (DeVito, 2013). Dalam kaitannya dengan penelitian ini, hasil wawancara menunjukkan bahwa di dalam hubungan yang dibangun para informan dengan mutual-nya telah terbangun kepercayaan, meskipun dalam tingkatan yang berbeda-beda antara satu informan dengan informan lainnya. Informan pada penelitian ini sebagian mempunyai tingkat kepercayaan yang cenderung tinggi dan sebagian lainnya sedang dan rendah. Pada tingkat kepercayaan yang cenderung tinggi keterbukaan diri cenderung sudah pada tahap mengetahui cerita kehidupan pribadi atau kehidupan nyata masing-masing, merasa cocok satu sama lain, dan menganggap teman dapat diandalkan.

Hal yang menarik dari penelitian ini adalah temuan bahwa salah satu dari informan yang memiliki tingkat kepercayaan yang rendah dalam hubungan pertemanan yang dibangun 
secara online cenderung memiliki tingkat kepercayaan yang rendah pula dalam hubungan pertemanan yang dibangun secara offline. Akan tetapi, ada pula informan yang memiliki tingkat kepercayaan yang cenderung lebih tinggi dalam hubungan yang terbangun secara online, justru lebih mempercayai teman dalam hubungan online nya dibandingkan dalam hubungan offline nya. Seperti yang dijelaskan oleh informan yang mempunyai tingkat kepercayaan tinggi kepada teman online-nya

"For me they (teman online) more open minded kayak mereka bisa menilai gua dari apa yang gua ceritain aja. Gak ada dari latar belakang gua, gerak-gerik gua, gossip-gosip yang ada di sekolah kayak gitu lah. Jadi gua lebih emm gimana yaa gua mendeskripsikannya yaa someone that I can trust more, walaupun misalnya mereka jadi betrayal gitu well they don't even know the real me jadi orang yang bisa aku bagi dan bisa aku lebih percaya gitu".

Di samping itu, penelitian ini juga menemukan bahwa kepercayaan yang terbangun di antara informan dengan mutual-nya memiliki kaitan yang erat dengan keterbukaan diri. Dalam hal ini, informan dengan kepercayaan 'sedang' pada mutual-nya cenderung lebih berhati-hati dalam mengungkap informasi personal serta saat berbicara pada teman onlinenya. Menurut informan, walaupun dirinya sering bercerita tentang kehidupan pribadinya namun dirinya selektif terhadap cerita yang dibagi misalnya tidak menunjukan nama atau kejadian spesifik. Hal tersebut mematahkan argumen dari penelitian sebelumnya yaitu penelitian McKenna bahwa anonimitas memungkinkan terjadinya pembentukan kepercayaan yaitu perasaan bahwa informasi pribadi yang diungkapkan tidak akan tersebar luas dan mengurangi rasa takut dan malu seseorang untuk membagi informasi seputar hal pribadi, karena tidak semua merasakan hal yang sedemikian (McKenna, 2002). Begitu pula dengan informan yang mempunyai kepercayaan yang cenderung rendah dengan teman onlinenya. Informan mengaku bahwa teman online tidak perlu mengetahui keadaan dirinya yang sebenarnya.

Kondisi sebaliknya terjadi pada informan dengan kepercayaan yang relatif tinggi pada mutual-nya. Informan dengan tingkat kepercayaan yang tinggi menjelaskan bahwa dirinya sangat terbuka kepada teman online-nya bahkan ia lebih terbuka dibanding pada teman offline-nya. Informan mengakui bahwa dirinya merasa nyaman dengan anonimitas sehingga jika ceritanya disebar pun, orang lain tidak akan mengetahui identitas dirinya yang sebenarnya. Seperti yang dijelaskan oleh salah satu informan "kalo dibilang lebih percaya tergantung apa dulu sih karena kalo gue sendiri kalo masalah sesuatu gua anggap lebih privasi gua lebih percaya sama temen online, gitu ya.". (BLD, 2 Januari 2020). Temuan ini berarti bahwa 
tidak semua individu yang menggunakan akun anonim percaya bahwa ceritanya tidak akan tersebar luas dan walaupun anonim. Individu masih mempunyai rasa takut untuk membagi informasi seputar hal pribadi.

Selanjutnya, informasi yang dimaksud berhubungan dengan topik yang dibicarakan. Topik yang dibicarakan dapat menentukan intimasi individu dalam sebuah hubungan. Saat hubungan menjadi lebih intimate atau intim, hubungan tersebut mencakup lebih banyak area dalam kehidupan (breadth) yaitu topik yang dibicarakan di antara dua individu semakin banyak, dan topik yang dibicarakan sudah mencakup topik yang sensitif dan penting (depth) atau dalam bahasa lain adalah individu satu sudah menembus kepribadian inti dari individu lainnya (Dwyer, 2002; DeVito, 2013).

Dari hasil penelitian diketahui bahwa masing-masing informan mempunyai tingkat depth dan breadth yang berbeda-beda. Sebagaimana terjadi pada informan dengan keterbukaan yang sedikit kepada mutual-nya yaitu pengungkapan diri yang masih terbatas yaitu tidak membicarakan topik-topik yang terlalu dalam misalnya tentang siapa dirinya, bagaimana kondisi keluarganya atau dalam kata lain tidak membicarakan kehidupan nyatanya. Topik obrolan pun sudah berkembang yang tadinya hanya membicarakan tentang K-pop saja lalu membicarakan topik lain seperti masalah kesehatan mental dengan intensitas komunikasi lebih tinggi (sering).

Di sisi lain, informan yang sudah menunjukan dimensi depth yang cukup dalam dan dimensi bredth yang cukup luas, topik yang dibicarakan sudah mulai mengarah pada kehidupan pribadinya di dunia nyata. Kecenderungan ini cukup besar khususnya pada informan yang mempunyai kepercayaan yang tinggi. Informan bahkan lebih mempercayai teman onlinenya daripada teman offlinenya. Informan mengaku bahwa mutual-nya sudah mengetahui siapa dirinya, di mana ia berkuliah, bahkan seperti apa kisah hidupnya. Seperti yang dikemukakan salah satu informan:

"gimana yaa gue seyakin itu sih. Kalo gue nih bicara sama temen-temen real life gue kayak misalnya yang gue ketemu waktu sma atau kuliah gue enggak bakalan ceritain kayak ke dia (temen online) karena kayak kalo gue cerita ke dia (teman online) gue seyakin itu dia ga bakal cerita ke orangorang gitu loh dan udah sampe disitu aja gitu”. (BLD, 1 Januari 2020).

Hal selanjutnya yang dikaji dari penelitian ini adalah pandangan informan terhadap hubungan pertemanan online yang dijalin. Masing-masing informan dalam penelitian ini mempunyai pandangan yang berbeda terhadap hubungan pertemanan online yang dijalani. Ada yang menganggap bahwa pertemanan virtual berbeda dengan pertemanan offline, ada pula yang menganggap bahwa pertemanan virtual sama dengan pertemanan di dunia nyata 
(mereka saling berbagi cerita dan menjalani hubungan pertemanan layaknya sudah pernah bertemu satu dengan lainnya). Bagi mereka yang menganggap pertemanan online dan offline berbeda, pertemanan online dianggap lebih mudah karena hanya memanfaatkan kemampuan berbahasa seseorang tanpa melihat fisik yang dapat menimbulkan penilaian lain (penilaian eksternal), mereka juga menilai bahwa mereka harus selektif dalam memilih teman untuk menghindari hal-hal yang tidak diinginkan seperti misalnya dimanfaatkan secara materil.

Hal ini seperti dikatakan oleh salah satu narasumber:

"Kalo offline tuh kayak apa ya keliatan kita bisa nilai orang dari mimic muka dari first impression kita, kita mau temenan sama orang itu liat dari...ya tanpa ada alasann yang pasti kita bisa ga suka sama orang. Tapi di online itu kita bisa liat dari katakata dia, cara dia peduli sama orang gitu sebenernya bedanya".

Narasumber lain juga mengatakan bahwa berteman secara online harus selektif guna menghindari hal negatif seperti dimanfaatkan orang lain:

"Kadang ada nih temenan online ujungujungnya kayak manfaatin kan kalo lu udah merasa nyambung. Kadang suka ada yang kayak gitu kan, orang udah berani pinjam duit. Selektif aja sih tan, dan untungnya ya, maksudnya untung-untungan juga dapetnya, untung aku bisa ketemu sama yang baik".

Selain temuan tentang terbentuknya trust dan beragam tahapan yang menunjukkan proses eskalasi pada friendship relationship, penelitian ini juga memperoleh temuan tentang cara informan merespon konflik. Secara mendasar, kehadiran konflik tidak selalu berarti negatif sebab sebagaimana dikemukakan Wood, konflik merupakan sebuah tanda bahwa individu saling terlibat satu sama lain (Wood, 2011). Hasil dari penelitian ini menunjukkan bahwa sebagian besar informan tidak pernah mengalami konflik yang besar dengan mutualnya, sebagian lainnya mengaku pernah mengalami konflik yang cukup besar yang berujung pada pemutusan hubungan. Informan menjelaskan bahwa dirinya mempunyai strategi preventif untuk mencegah terjadinya konflik yaitu dengan menghindari obrolan atau topik yang dapat menimbulkan konflik, sejak awal aturan tersebut telah dibicarakan, seperti yang disampaikan oleh salah satu informan:

"Ya contohnya aja gua ga pernah mau ngomongin dia (idol yang disuka laki-laki) sama idol cewe. Itu pokoknya, gua sama dia gamau ngepairing-ngepairing idol cowo sama idol cewe gitu loh. Jadi kayak. pokoknya jangan ngomongin itu deh". (DS, 10 Januari 2020).

Sementara itu informan-informan yang mengalami konflik kecil menjelaskan bahwa strategi yang digunakan untuk mengelolanya cukup dengan membicarakan baik-baik atau menganggap konflik tersebut tidak ada seiring berjalannya waktu. Hal ini sangat 
menggambarkan ciri khas orang-orang pada collectivistic culture yang cenderung menggunakan avoiding style dalam merespon konflik (Ting-Toomey \& Chung, 2012). Cara merespon ini bagi Wood dipandang berpotensi pada kondisi yang destruktif sebab neglected response tidak secara aktifmendorong terjadinya diskusi aktif (Wood, 2011). Sementara itu, ketiadaan konflik yang besar dalam hubungan mereka diakui karena informan dan mutual-nya sudah merasa cocok satu sama lain atau sifat bawaan individu yang cenderung menghindari konflik baik di dalam pertemanan offline maupun online. Seperti pernyataan narasumber berikut ini "Kebanyakan sih kalo misalnya ada konflik, mengatasinya yaa ini aja sih as time pass aja sih kalo misalnya udah ini yaa udah biasa lagi. Sebenernya diomongin baik-baik aja sih, intinya kayak agree to disagree aja sih".

Dari informan yang pernah mengalami konflik besar yang berujung pada pemutusan hubungan diketahui bahwa pemutusan hubungan terjadi karena usaha yang tidak dihargai. Pemutusan hubungan tersebut ditandai dengan saling unfollow (berhenti mengikuti) dan blokir satu sama lain. Hasil temuan ini serupa dengan hasil penelitian dari Dewi yang membahas tentang cyber-romantic relationship bahwa dalam merespon konflik individu cenderung less-emotional dan lebih tenang serta cenderung untuk lari dari permasalahan (Dewi,
2013). Hal tersebut dikarenakan kemudahan dalam dunia cyber yaitu disconnect atau dalam fitur Twitter itu sendiri unfollow dan blokir. Salah satu narasumber menjelaskan saat setelah terjadinya konflik yang dialami, "Habis itu yaudah dia ngeblok-unblock gue. Yaudah udah akward sampe sekarang gua ga pernah sapasapa-an lagi”.

Hal yang dilakukan informan pada konflik yang dialaminya yaitu berusaha untuk meminta maaf ataupun hal yang dilakukan informan lain dalam konflik kecil untuk membicarakannya terlebih dahulu daripada pemutusan hubungan dilakukan karena adanya keinginan untuk mempertahankan hubungan. Mereka beranggapan bahwa konflik dapat berujung pemutusan hubungan yang selama ini telah dibangun. Hasil dalam penelitian ini juga serupa dengan penelitian dari Ishii bahwa ketika terjadi konflik individu tidak selalu menunjukkan tingkat kepedulian yang relatif tinggi terhadap mitra online mereka, namun bagi mereka yang mempunyai keinginan untuk mempertahankan hubungannya mereka cenderung menggunakan gaya manajemen konflik yang kooperatif yaitu berhati-hati untuk tidak mementingkan diri sendiri ataupun memutuskan hubungan secara sepihak (Ishii, 2010).

Terlepas dari respon terhadap konflik, pandangan informan terhadap hubungan pertemanan online dalam penelitian ini 
juga dapat dilihat dari bagaimana individu menjaga hubungan pertemanan mereka. Dalam hal pemeliharaan hubungan, informan menggunakan fitur-fitur yang ada di media sosial Twitter sebagai media komunikasi untuk menggantikan elemen komunikasi tatap muka.

Fitur-fitur tersebut seperti DM, reply, dan likes. Kecenderungan salah satu pihak untuk memulai komunikasi melalui fitur menjadi pendukung lancarnya komunikasi di antara dua pihak. Fiturfitur tersebut pun mempunyai fungsinya sendiri bagi informan dalam kehidupan pertemanan daring yang dijalani, misalnya DM digunakan untuk berkomunikasi terkait hal yang dianggap privat atau tidak ingin diketahui orang lain, reply \& quote untuk memberikan feedback terhadap tweet mutual, dan likes sebagai pertanda bahwa pengguna menyukai tweets pengguna yang lain.

DeVito memaparkan bahwa rules dalam hubungan interpersonal bersifat pribadi karena aturan ditetapkan oleh perorangan yang menjadikan aturan sosial atau adat sosial menjadi tidak begitu penting bagi rules dalam hubungan interpersonal (DeVito, 2011). Shimanoff memaparkan bahwa aturan bersifat followable prescription atau resep yang harus diikuti yang menunjukan perilaku apa yang diwajibkan, disukai, atau dilarang dalam konteks tertentu (Rios, 2001; DeVito, 2013).

Hasil dari penelitian ini menunjukan bahwa seluruh informan mengakui adanya aturan yang turut andil dalam dinamika hubungan mereka. Hal ini sejalan dengan pendapat dari Blieszer \& Adam bahwa friendship are likely governed by specific set of interaction rules (friendship rules), yang berarti hubungan pertemanan kemungkinan diatur oleh seperangkat aturan pertemanan (Bryant \& Marmo, 2012). Dari hasil penelitian ini diketahui bahwa aturan yang ada dalam pertemanan di Twitter dengan akun anonim dibuat secara sadar maupun tidak sadar. Sadar dalam hal ini berarti bahwa ada kesepakatan dari awal terbentuknya pertemanan serta tidak disadari yang berasal dari kebiasaan yang akhirnya menjadi aturan. Temuan ini sejalan dengan pendapat dari Rios bahwa aturan dapat dilihat secara tersirat (tidak disadari) dan dapat disimpulkan dari suatu situasi maupun dinyatakan dengan jelas (sadar) (Rios, 2001).

Aturan-aturan yang disusun dengan kesepakatan awal cenderung merupakan aturan khusus, misalnya aturan terkait minat informan yaitu aturan untuk tidak membicarakan kehidupan pribadi idola dan romansa idola. Aturan tersebut dibuat karena antara dua individu mempunyai minat yang sama dan sama-sama tidak menyukai topik pembicaraan tersebut yang berujung pada dibuatnya aturan. Sedangkan, aturan-aturan yang dibentuk oleh kebiasaan yang berujung kesepahaman cenderung merupakan aturanaturan yang umum, misalnya aturan untuk 
berbagi cerita dengan satu sama lain, aturan mengenai dukungan, dan aturan untuk tidak membicarakan topik mengenai keluarga.

Bryant \& Marmo menjelaskan kategori aturan mempertahankan dan mengisyaratkan kedekatan (intimacy) yang dicontohkan dengan pengungkapan diri (self-disclosure), diskusi mengenai topik yang bersifat pribadi, ekspresi kemarahan/ kecemasan (expression of anger/ anxiety), dan kepercayaan (Bryant \& Marmo, 2012). Dalam penelitian ini ditemukan bahwa pada pengungkapan diri oleh masing-masing individu dalam hubungan pertemanan yang terbentuk secara online, disepakati bahwa tidak ada aturan khusus yang mengatur bahwa seseorang harus menunjukan siapa dirinya, hal ini tidak terlepas dari disamarkannya identitas informan melalui penggunaan akun anonym. Sehingga mengungkapkan identitas diri menjadi tidak begitu penting untuk diketahui.

Walaupun lama kelamaan sebagian dari informan mengungkapkan informasi personal, termasuk identitas riilnya, namun mereka menyepakati tentang tidak adanya keharusan untuk mengungkap informasi personal atau privat di dalam hubungan tersebut. Berkaitan dengan poin kedua yang dipaparkan Bryant \& Marmo yaitu mengenai diskusi mengenai topik yang bersifat pribadi, temuan dalam penelitian ini menunjukkan bahwa bagi informan yang mempunyai tingkat keterbukaan tinggi, topik yang bersifat pribadi menjadi umum atau lumrah untuk dibicarakan (Bryant \& Marmo, 2012). Namun, bagi mereka yang mempunyai tingkat keterbukaan yang rendah topik pribadi menjadi larangan untuk dibicarakan. Hal ini menjadikan topik pembicaraan sebagai salah satu aturan yang ada dalam hubungan pertemanan online.

Hal yang menarik dari penelitian ini yaitu temuan bahwa semua informan melarang topik pembicaraan seputar keluarga, masalah keluarga atau kondisi ekonomi untuk dibahas dalam hubungan pertemanan yang mereka jalani. Sebagian informan tidak membicarakan kehidupan pribadinya seperti masalah percintaan atau masalah yang terjadi di dunia nyata. Temuan ini menjadi menarik sebab dalam hubungan pertemanan yang sifatnya dekat, pengungkapan private information terjadi secara alamiah dan membawa pada semakin tingginya intimacy dalam hubungan. Akan tetapi, informan dalam hubungan friendship secara online ini justru secara jelas membatasi pembicaraan yang mengarah pada pengungkapan informasi privat berkaitan dengan keluarga. Kesepakatan ini dimunculkan dalam aturan yang mengikat keduanya dalam hubungan yang mereka jalani.

Bryant \& Marmo juga menjelaskan aturan tentang pertukaran imbalan yang tepat atau proper exchange reward, misalnya tentang dukungan emosional dan bantuan yang bersifat sukarela (Bryant \& Marmo, 2012). Penelitian 
ini menemukan bahwa dukungan emosional dalam pertemanan online berupa perhatian, support, saran, semangat melalui tweet terhadap tweet informan yang mengandung unsur kesedihan atau jika informan bercerita sendiri mengenai pengalaman sedihnya. Hal tersebut harus dilakukan jika salah satu menunjukan tanda-tanda membutuhkan dukungan, salah satu informan menjelaskan bahwa menanggapi dan mendukung saat sedang down sangat diperlukan. Informan lain juga mengungkapkan bahwa dirinya harus menjadi pihak pertama yang mengetahui kesedihan yang dialami mutualnya.

Pemberian dukungan emosional menjadi salah satu aturan dalam hubungan pertemanan online. Aturan ini dapat dikaitkan dengan konsep friendship needs sebagaimana dipaparkan oleh DeVito bahwa individu mencari teman atau pasangan dengan mempertimbangkan kebutuhan yang dapat disediakan oleh teman/ pasangan(DeVito, 2013). Pada penjelasan di atas terlihat jelas bahwa proper exchange rewards menjadi aturan karena informan membutuhkan dan mencari dukungan emosional yang bisa didapat dari teman online.

Emotional support ini termasuk dalam friendship needs dukungan ego, yaitu teman yang berperilaku mendukung, mendorong, dan membantu. Seperti yang disampaikan oleh salah satu informan:
"Kalo dukungan ya dari dm-dm gitu aja misalnya kalo dia lagi down yaa dia bilang dia lagi agak gak enak nih, yaudah aku semangatin. Begitu juga aku, iya aku lagi agak ribet banyak ini banyak itu dia juga semangatin”. (NM, 10 Januari 2020).

Selain itu dalam penelitian ini ditemukan juga aturan mengenai konflik atau potensi konflik. Salah satunya adalah aturan untuk tidak menyerang privasi antar teman karena akan berujung konflik. Seperti yang diungkapkan oleh seorang informan:

"lebih ke saling agree aja sih, misalnya kita berdua sama-sama ga ngomongin ranah pribadi, misalnya kayak yang tadi permasalahan keluarga. Itu sebenernya kayak semacam aturan yang gak diomongin sih tapi kita berdua sama-sama tau”. (NM, 10 Januari 2020).

Sedangkan aturan yang mengatur potensi konflik lainnya dari penelitian ini ditemukan yaitu gathering opinion sebelum menghakimi, aturan membela teman di Twitter, karena di Twitter sering muncul konflik yang bermula dari ketidaksepahaman, dari sini peran teman dibutuhkan untuk membela atau membantu jikalau salah satunya mengalami perundungan.

Temuan dalam penelitian ini juga menunjukkan bahwa tiga dari empat informan mengaku bahwa pernah mengalami kecemburuan di dalam hubungan pertemanan virtualnya, namun tidak ada aturan yang menonjol yang mengatur potensi konflik dari pihak ketiga. Menurut pendapat lain yaitu 
dari Dwyer, aturan ini disebut dengan jenis rules behavior with third parties (Dwyer, 2002). Aturan ini menjelaskan bahwa aturan perilaku dengan pihak ketiga diperlukan untuk mengontrol perilaku dalam kaitannya dengan orang lain. Aturan ini membantu untuk mengatasi masalah kecemburuan, menjaga kerahasiaan dan membela seseorang dalam ketidakhadiran mereka.

Aturan lain yang ditemukan di dalam penelitian ini adalah aturan tentang penggunaan fitur tertentu di Twitter dalam hubungan pertemanan virtual yang ditemukan dalam kategori di atas. Aturan ini berbicara tentang bagaimana fitur-fitur Twitter seperti DM, reply, quote, $R T$, dan likes menjadi penting bagi sarana komunikasi mereka yang masing-masing mempunyai fungsinya sendiri. Hal ini tentunya berbeda bahkan tidak ada jika dibandingkan dengan aturan di dalam hubungan pertemanan non-virtual. Seperti pada likes, yang dapat masuk dalam kategori mengisyaratkan kedekatan (intimacy). Menurut para informan like wajib digunakan pada saat mutual membuat tweet, informan menjelaskan bahwa hal ini sebagai bentuk support atau dukungan serta antusiasme kepada teman onlinenya yang tidak bisa dilakukan dengan cara yang sama seperti ketika dengan teman offline. Seperti yang disampaikan oleh salah satu informan, "kalo like tuh biasanya gua rasa pentinggg banget, kalo tweet ya buat jb-jb orang aja” (DS, 10 Januari 2020). Selain itu, mention, quote, dan reply yang mempunyai fungsi sama yaitu memberikan feedback juga menjadi keharusan jika mutual men-tweet sesuatu, pada fitur ini bukan lagi pertanda melainkan sudah berupa kata-kata. Fungsi lain dari fitur tersebut adalah agar antar dua individu keep in contact dan sebagai bukti kepada mutual lain bahwa keduanya sedang menjalani hubungan yang baik-baik saja. Fitur yang terakhir adalah DM atau direct message yang digunakan untuk berkirim pesan yang cenderung privat atau tidak ingin diketahui orang lain, pada saat pembicaraan sudah mengarah ke privat, otomatis pengguna sadar melalui fitur apa pembicaraan ini harus dibicarakan.

Jika dilihat dari konsep yang dikemukakan Bryant \& Marmo (2012) dan Dwyer (2002), maka aturan tentang penggunaan fitur tidak ditemukan dalam kedua konsep yang dipaparkan oleh peneliti tersebut. Selain itu, aturan pengungkapan diri yang dikemukakan oleh Bryant \& Marmo juga tidak ditemukan di dalam aturan hubungan pertemanan online dengan akun anonim (Bryant \& Marmo, 2012). Pada penelitian ini ditemukan aturan mengenai fitur yang digunakan karena dalam pertemanan online individu memerlukan fitur-fitur yang dapat menggantikan hal yang biasa dilakukan di pertemanan offline, seperti yang telah dijelaskan sebelumnya misalnya fitur like sebagai fungsi 
afeksi. Lalu, aturan tentang pengungkapan diri yang tidak ditemukan dalam pertemanan online karena masing-masing dari individu sudah memahami bahwa tujuan dari menggunakan akun anonim adalah untuk menutupi identitas, sehingga pengungkapan diri tidak menjadi suatu keharusan.

Berdasarkan hasil penelitian yang dilakukan, informan tidak mempunyai sanksi per kategori aturan yang sudah dijelaskan sebelumnya, melainkan sanksi berlaku secara umum untuk aturan-aturan yang dilanggar dalam hubungan pertemanan virtual. Berdasarkan hasil wawancara, pada saat aturan dilanggar tidak ada sanksi yang terlalu tegas yang diberikan oleh informan. Jawaban dari hasil wawancara pada saat aturan dilanggar rata-rata adalah menjauhi mutualnya untuk beberapa saat, menegur mutualnya, dan memaafkan. Strategi tersebut tidak menimbulkan konflik yang besar. Namun diakui bahwa hal ini bergantung pada respon mutualnya juga, jika pada saat proses 'menjauh untuk sementara' mutualnya memilih untuk memutuskan hubungan, informan hanya bisa menerima keputusan tersebut. Dari hal tersebut diketahui bahwa sanksi terbesar dilanggarnya aturan adalah pemutusan hubungan pertemanan.

Berangkat dari seluruh proses analisis data sebagaimana telah dipaparkan sebelumnya, penelitian ini menemukan adanya kecenderungan yang menunjukkan keterkaitan antara bentuk aturan yang diberlakukan dalam hubungan pertemanan yang dijalani informan dengan akun anonim melalui Twitter dengan keterbukaan dan derajat kepercayaan (trust) yang berlaku dalam hubungan pertemanan tersebut. Kecenderungan tersebut dalam penelitian ini berusaha digambarkan melalui model sehingga diharapkan dapat menunjukkan detail pengalaman informan terkait friendship relationship yang dibangun secara online melalui akun anonim.

Melalui penggunaan konsep fenomenologi sosial oleh Schutz, penelitian ini menemukan 2 jenis motif yang mendasari informan dalam membangun hubungan pertemanan dengan akun anonim melalui Twitter. Menurut Gerungan, motif merupakan pengertian yang melengkapi semua penggerak alasan-alasan yang ada pada diri manusia yang kemudian mendorong mereka melakukan sesuatu (Sunaryo, 2004). Adapun 2 jenis motif tersebut yaitu "motif menyalurkan minat terhadap K-Pop" dan "motif untuk mencari kehidupan yang lain".

Secara konseptual, Schutz menyebutkan bahwa terdapat 2 motif yang mendasari tindakan individu yaitu because motive dan in order to motive sebagai upaya menganalisis tindakan bermakna dalam konteks internal time consciousness (Schutz, 1972). Dalam hal ini, because motive merujuk pada fase motif pada masa lalu (Kuswarno, 2009). Because 
motive merupakan faktor yang menyebabkan seseorang melakukan tindakan tertentu dan tindakan ini muncul melalui proses yang panjang dan mempertimbangkan kondisi sosial, ekonomi, budaya, dan norma etika agama atas dasar tingkat kemampuan pemahaman sendiri sebelum tindakan itu dilakukan (Lailiyah \& Affandi, 2015). Di sisi lainnya, in order to motive digunakan Schutz untuk menunjukkan fase motif pada masa yang akan datang (Kuswarno, 2009), alasan seseorang untuk melakukan sebuah tindakan untuk menciptakan kondisi tertentu di masa mendatang (Lailiyah \& Affandi, 2015).

Jika dikaitkan dengan 2 jenis motif menurut Schutz, maka motif yang mendasari informan untuk menjalani hubungan pertemanan tersebut terkategori sebagai because motive. Hal ini didasarkan pada kondisi bahwa "menyalurkan minat terhadap K-Pop" maupun "mencari kehidupan yang lain" tidak muncul begitu saja, tetapi muncul dari pengalaman informan dengan beberapa jenis hubungan yang dijalani secara offline maupun online dengan menggunakan identitas riil mereka. Sejarah hubungan pertemanan sebelumnya turut membentuk rangkaian tindakan yang dilakukan hingga informan memutuskan untuk menjalin hubungan pertemanan melalui Twitter dengan menggunakan akun anonim. Seperti yang ditunjukkan informan dengan motif untuk mencari kehidupan yang lain. Motif tersebut berarti bahwa informan menjalin hubungan pertemanan melalui Twitter dengan akun anonim sebab mereka ingin keluar dari topik zona nyaman dan mencari informasi atau berita di dunia luar sehingga dapat menambah ilmu dan belajar untuk melihat sesuatu dari sudut pandang yang berbeda. Kondisi ini tidak terlepas dari sejarah hubungan pertemanan yang telah dijalani sebelumnya.

Penelitian yang dilakukan oleh Dhea dan Nofha menunjukkan bahwa Motif Interpersonal Utility dalam penggunaan media sosial Twitter pada pengikut akun Twitter@ EXOind memperoleh nilai rata-rata yang termasuk ke dalam kategori "tinggi”, di mana indikator yang digunakan dalam variabel ini di antaranya bertemu dan berkenalan dengan orang baru, saling memberikan saran dan opini, mendapat lebih banyak sudut pandang, dan mendapatkan bantuan dari orang lain (Dhea dan Nofha, 2020). Indikator-indikator tersebut menunjukkan bahwa adanya "because motive", yaitu untuk menyalurkan minat terhadap K-Pop dan juga mencari kehidupan yang lain.

Secara keseluruhan, keterkaitan antara motif yang mendasari dibangunnya hubungan pertemanan melalui Twitter dengan akun anonim dengan keterbukaan, derajat kepercayaan dan aturan yang terbangun dalam hubungan tergambar melalui gambar 1 dan gambar 2 . 


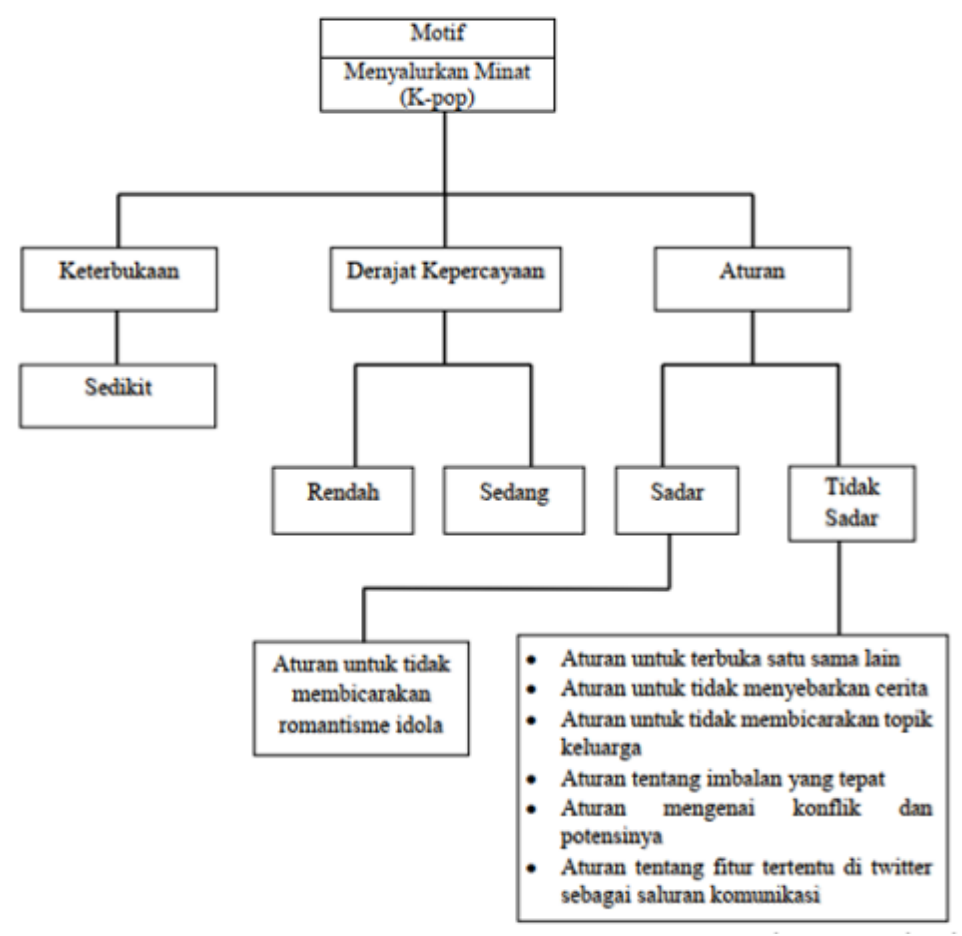

Sumber: Data peneliti, 2020

Gambar 1 Model keterkaitan motif "menyalurkan minat terhadap K-Pop" dengan keterbukaan, derajat kepercayaan dan aturan yang terbangun dalam hubungan pertemanan

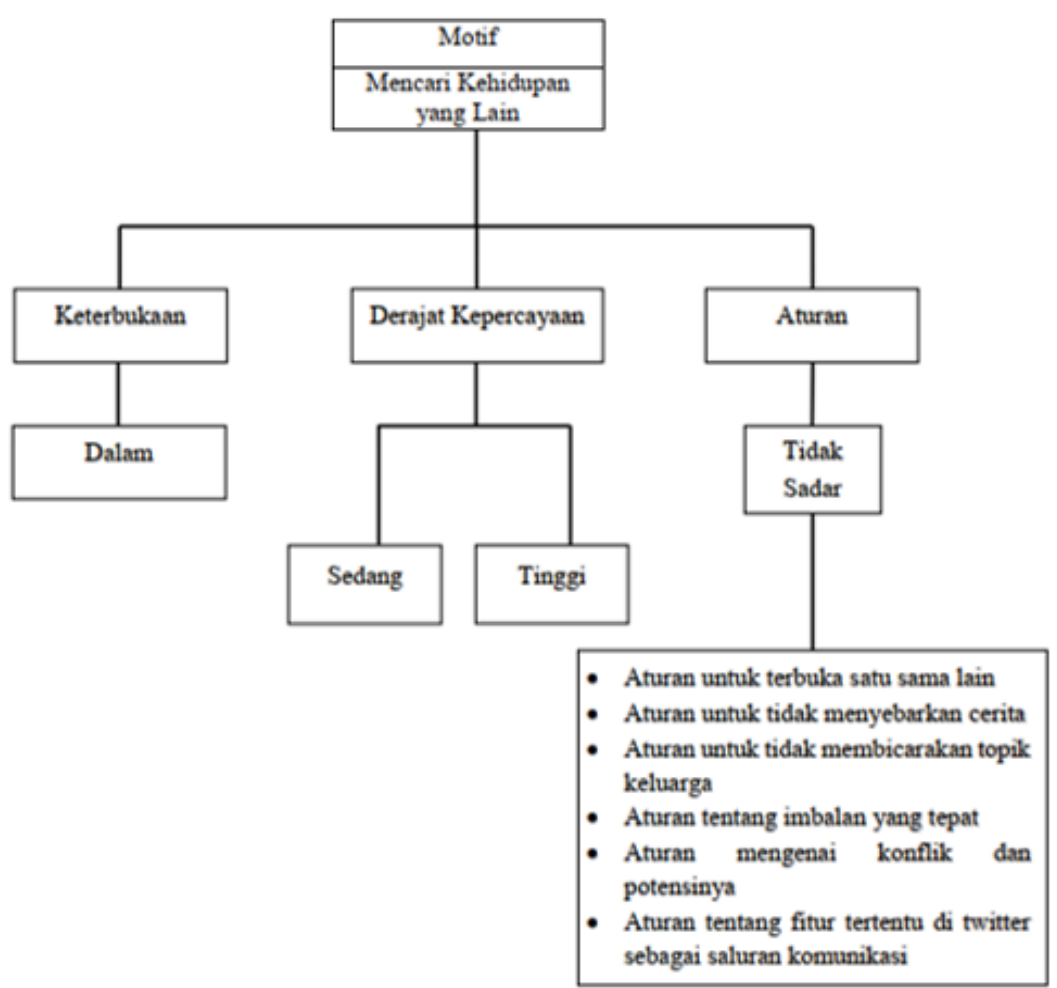

Sumber: Data peneliti, 2020

Gambar 2 Model keterkaitan motif "mencari kehidupan yang lain" dengan keterbukaan, derajat kepercayaan dan aturan yang terbangun dalam hubungan pertemanan 


\section{SIMPULAN}

Berdasarkan seluruh proses analisis data dapat disimpulkan bahwa hubungan yang dibangun melalui Twitter dengan akun anonim oleh para informan dapat didefinisikan sebagai hubungan pertemanan karena adanya dukungan emosional antara informan dan mutualnya, adanya minat yang sama, serta adanya kepercayaan walaupun dalam tingkat yang berbeda-beda antar informan. Aturan pun turut mendukung dinamika hubungan pertemanan akun anonim. Aturan-aturan yang ada di dalam hubungan pertemanan oleh akun anonim adalah aturan untuk tidak membicarakan kehidupan pribadi idola dan romansa idola, aturan mengenai topik yang boleh dan tidak boleh dibicarakan (termasuk aturan mengenai diskusi topik pribadi), aturan untuk menjaga informasi, aturan tentang imbalan yang tepat (proper exchange meaning), serta aturan mengenai konflik dan potensinya. Aturan tersebut untuk mempertahankan reward yang tidak mereka dapatkan pada hubungan pertemanan tatap muka dan bukan anonim. Keterbukaan, derajat kepercayaan dan aturan yang dibangun dan berlaku secara berbeda di dalam hubungan pertemanan bergantung pada motif yang mendasari informan dalam membangun hubungan pertemanan melalui Twitter dengan akun anonim.

\section{DAFTAR PUSTAKA}

Ardi, R. (2017). Anonimitas dan pemenuhan kebutuhan psikososial melalui pengungkapan diri di media sosial. Dalam Psikologi dan Teknologi Informasi (Seri Sumbangan Pemikiran Psikologi Untuk Bangsa 2) (hal. 379-399). Himpunan Psikologi Indonesia. Diambil kembali dari https://www.researchgate.net/ publication/328224789_Anonimitas_dan_ Pemenuhan_Kebutuhan_Psikososial_ Melalui_Pengungkapan_Diri_di_Media Sosial

Argyle, M., \& Anderson, M. (1984). The rules of friendship. Journal of social and personal relationship, 1, 211-237.

Berger, Charles R, Roloff, Michael E., dan Ewoldsen, David R.Roskos. (2014). Handbook Ilmu Komunikasi. Bandung: Penerbit Nusa Media.

Blieszer, R. A. (1992). Adult Friendship. California: Sage Publication

Bryant, E. M., \& Marmo, J. (2012). The rules of facebook friendship: a twostage examination of interaction rules in close, casual, and acquaintance friendships. Journal of Social and Personal Relationship(29), 1013-1035.

Bubas, G., \& Bratko, D. (2008). Factor analysis of rules in: relations of personality traits and friendship quality. the 58th Annual Conference of the International Communication Association (ICA 2008).

Creswell, J.W. (2013). Qualitative inquiry and research design: choosing among five approaches third edition. Thousand Oaks: Sage Publications.

DeVito, J. (2011). Komunikasi antarmanusia (5th ed.). (A. Maulana, Penerj.) Tangerang Selatan: Kharisma Publishing Group. 
DeVito, J. (2013). The interpersonal communication book (13th ed.). England: Pearson New International Edition.

Dewi, M. (2013). Strategi individu yang terlibat cyber-romantic relationship $(C R R)$ dalam merespon perselingkuhan dalam hubungannya. Universitas Airlangga. Surabaya: Repository Unair. Diambil kembali dari http://repository.unair. ac.id/16223/

Dhea N L, Nofha R (2020), Motif Penggunaan Media Sosial Twitter (Studi Deskriptif Kuantitatif Pada Pengikut Akun Twitter @EXOind) 20 (1), 63-71. Retrieved from https://doi.org/10.31294/jc.v19i2

Dwyer, D. (2002). Interpersonal relationship. London: Routledge.

Fereday, J., Muir-Cochrane, E. (2006). Demonstrating rigor using thematic analysis: a hybrid approach of inductive and deductive coding and theme development. International journal of qualitative methods, 5, (1), 80-92. DOI: 10.1177/160940690600500107.

Griffin, E. (2009). A first look at communication theory. New York: McGraw Hill.

Hasbiansyah, O. (2005). Pendekatan fenomenologi: pengantar praktik penelitiandalam ilmu sosial dan komunikasi. . Mediator, 9(1), 163-180.

Ishii, K. (2010). Conflict management in online relationship. Cyberphysychology, Behaviour, and Social Networking, 13(4), 365-370.

Kriyantono, R. (2006). Teknik praktis riset komunikasi: disertai contoh praktis riset media, public relations, advertising, komunikasi organisasi, komunikasi pemasaran. Jakarta: Kencana Prenadamedia Group.

Kuswarno, E. (2007). Tradisi fenomenologi pada penelitian komunikasi kualitatif. Sosiohumaniora, 9(2), 161-176.

Kuswarno, E. (2009). Metodologi penelitian komunikasi: fenomenologi, konsepsi, pedoman dan contoh penelitiannya. Bandung: Widya Padjadjaran.

Lailiyah, A.N., Affandi, M.A. (2015). Pengajian virtual: studi tentang motif sebab dan tujuan ngaji dalam dunia virtual bagi ODOJers di komunitas one day one juz. Paradigma, 3, (3), 1-8.

McKenna, K., Green, A., \& Gleason, M. (2002). Relationship formation on the internet: what's the big attraction? Journal of Social Issue, 58(1), 9-31. doi:10.1111/15404560.00246

Nasrullah, R. (2014). Teori dan riset media siber (cybermedia). Jakarta: Kencana Prenada Media Group.

Nindito, S. (2005). Fenomenologi Alfred Schutz: studi tentang konstruksi makna dan realitas dalam ilmu sosial. Jurnal ilmu komunikasi, 2, (1), 79-94.

Parks, M., \& Floyd, K. (1996). Making friends in cyberspace. Journal of Communication, $\quad 46(1), \quad 80-97$. doi:10.1111/j.1460-2466.1996.tb01462.x

Ratnasari, Y. (2017, November 8). Twitter resmi menambah batasan kicauan jadi 280 karakter. Diambil kembali dari tirto.id: https://tirto.id/Twitter-resmi-menambahbatasan-kicauan-jadi-280-karakter-czNm.

Rios, M. (2001). Playing by the rules: relationship with online users. Diambil kembali dari Institutue of PR: www. instituteforpr.org

Sari, A. (2014). Hubungan antara penggunaan jejaring sosial Twitter dengan pengendalian diri pada mahasiswa fakultas psikologi angkatan 2013-2014 universitas muhammadiyah surakarta. Universitas 
Muhammadiyah Surakarta, Fakultas Walther, J., Anderson, J., \& Park, D. (1994). Psikologi, Surakarta.

Schutz, A. (1972). The phenomenology of the social world. Translated by George Walsh and Frederick Lehnet. London: Heinemann Educational Books.

Severin, J., \& Tankard, W. (2011). Teori Komunikasi: Sejarah, Metode, dan Terapan di Media Massa. Jakarta: Kencana.

Tang,L.(2010).Developmentofonline friendship in different social spaces. Information, Communication \& Society. Information, Communication, and Society, 4(13), 615633. doi:10.1080/13691180902998639

Ting-Toomey, S., Chung, L.C. (2012). Understanding intercultural communication. Oxford: Oxford University Press.

Vaquera, E. K. (2008). Friendship Reciprocity and Its Effects on School Outcomes among Adolescents. Social Science Research, 37(1), 55-72. Interpersonal effects in computer-mediated interactions a meta-analysis of social and antisocial communication. Communication Research, 4(21), 460-487.

Waskul, D., \& Douglass, M. (1997). Cyberself: The Emergence of Self in On-line Chat. The Information Society, 375-397.

Wijaya, C., \& Paramita, S. (2019, July). Komunikasi virtual dalam game online (studi kasus dalam game mobile legends). Koneksi, 3(1), 261-261.

Wood, A., \& Smith, M. (2005). Online communication: linking technology, identity, and culture (2nd ed.). London: Lawrence Erlbaum Associates Publishers.

Wood, J. T. (2010). Interpersonal communication: everyday encounters (6th ed.). USA: Wadsworth.

Wood, J.T. (2011). Communication mosaics: an introduction to the field of communication, sixth edition. Boston: Wadsworth. 